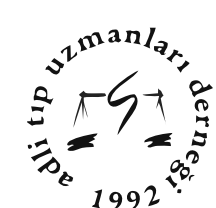

1992

\title{
Toplumsal Olaylarda Güvenlik Güçlerinin Müdahalelerine Bağlı Yaralanmaların Adli Raporlama Süreçleri: Olgu Serisi
}

\section{Forensic Reporting Process of Injured Cases as a Result of Security Forces Intervention to Protest Demonstrations: Case Series}

\author{
İlker Koçar, Ökkeş Koçyataği, Hakan Kar, Nursel Gamsız Bilgin, Halis Dokgöz
}

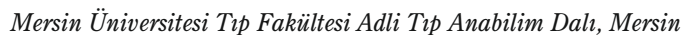

\section{Özet}

Ülkemizde protesto gösterisi ve toplumsal olaylarda güvenlik güçlerinin müdahaleleri sonucu çok sayıda yaralanma ve ölüm olguları görülebilmektedir. Bireylerin kendi sağlık durumunun tespiti, kayıt altına alınması ve dokümantasyonu ile yaralanmalarının tedavisi hususlarında sağlık kuruluşlarına bireysel başvuru hakkı hem Anayasa hem de uluslar arası antlaşmalar tarafından güvence altına alınmış olmasına rağmen güvenlik güçlerinin müdahaleleri sonucu yaralanan bu olgularının bireysel adli raporlama süreçlerinde hem soruşturma makamları hem de sağlık kurumları açısından birçok sıkıntı yaşanabilmektedir.

Anahtar kelimeler: Toplumsal olay, Protesto gösterisi, Yaralanma, Bireysel başvuru, Adli rapor.

\section{Giriş}

Adli Travmatolojide, yaralanmaların ağırlı̆̆ının tespit edilerek, hukuki süreçte değerlendirilmek üzere adli rapor düzenlenmesi esas alınmaktadır. Bu sürecin sağlıklı yürütülebilmesi için travmatik lezyonların zaman kaybetmeden belgelenmesi, kayıt altına alınması ve belgelenmesi gerekmektedir. Ülkemizde yaralanmalara bağlı adli rapor istemleri; Cumhuriyet Savcılıkları, Mahkemeler ve Güvenlik Kurumları (Polis, Jandarma vs.) aracılığıyla gönderilmekte ve çoğunlukla Adli Tıp Kurumu'na bağlı birimler ve Üniversite Tıp Fakültelerine bağlı Adli Tıp Anabilim Dalları tarafından bu istemler cevaplanmaktadır. Ayrıca yaralanan kişilerin resmi kurumlara başvurmadan, travmatik lezyonların tespiti, tanımlanması, delillendirilmesi (fotoğraf, lab vs.), lezyonların orijini, oluşma zamanı ve mekanizması, travmanın ağırlığının tespiti ile ruh sağlı̆̆ı üzerine etkilerinin tespit edilerek adli raporlanması ve arşivlenmesi hususlarında bireysel başvuru hakkı da bulunmaktadır. Adli Tıp Kurumu'na bağlı birimler, sadece resmi yolla gönderilen kişilere adli rapor düzenleyebilirken, Üniversite Tıp Fakültelerine bağlı Adli Tıp

\section{Abstract}

Many injuries, even deaths can be seen as a result of the intervention of the security forces to protest demonstration or social events in our country. The right of individual application to medical facilities for their health status and treatment is ensured by constitutional law and international legal regulations. Despite this assurance many problems can occur during forensic reporting process concerned with both medical facilities and judicial authorities.

Keywords: Social event, Protest demonstration, Injury, Individual application forensic report.

Anabilim Dalları resmi başvuruların yanı sıra bireysel başvuruda bulunan kişilere de hizmet verebilmektedirler (1).

Toplantı ve gösteri yürüyüşü yapmak anayasa tarafından güvence altına alınmış temel bir hak olmasına ve güvenlik güçlerinin toplumsal olayların güvenliğini sağlanmasında ve kontrolünde nasıl davranması gerektiği yasalarda ve uluslararası anlaşmalarda açıkça belirtilmesine rağmen, güvenlik güçlerinin müdahaleleri sonucu çok sayıda yaralanma ve ölüm olguları görülebilmektedir. Bu olaylarda güvenlik görevlilerinin aşırı güç kullanımının psikolojik, bireysel, toplumsal, ekonomik, sosyal, yasal ve kurumsal nedenleri olduğu belirtilmektedir (2). Ülkemizde toplumsal olaylarda güvenlik güçlerinin müdahalelerine bağlı yaralanmaların bireysel başvuru hakkı çerçevesinde adli raporlama süreçlerinde birçok sıkıntı yaşanabilmektedir. Bazen güvenlik güçleri ve Cumhuriyet Savcılıkları bireysel başvuru hakkı çerçevesinde düzenlenen adli raporlara şüpheyle yaklaşabilmekte ve sıklıkla resmi bir yazı ile aynı şahıs ve aynı olay hakkında Adli Tıp Kurumu'ndan tekrar rapor talep edebilmektedirler. Ayrıca güvenlik güçleri şikayet dilekçesini ve ekinde yer alan şikayete esas teşkil eden adli raporu, resmi olmadığ 1 ve böyle bir talepleri olmadığ 1 gerekçesiyle kabul etmeyebilmektedirler. Tüm bu sorunların yanı sıra başvurulan sağlık kurumları açısından da bir takım 
problemler ortaya çıkabilmektedir. Örneğin bazı sağlık kurumları bireysel başvuru hakkı çerçevesinde kendilerine başvuran hastalara adli rapor düzenlemeyi reddetmekte ve resmi kurumlardan istem yazısı talep etmektedirler (3). Bazı sağlık kurumları ise adli birimlerine bireysel başvuruları, Sosyal Güvenlik Kurumu üzerinden, ayaktan hasta girişi şeklinde, bazıları ise ücretli hasta statüsünde kabul etmektedirler. Ayrica bu hastalara verilen hizmetlerin faturalandırılma süreçlerinde de sıkıntılar meydana gelebilmektedir. Faturaların karşılanacağı adli birimler, resmi makamlarca adli rapor istem yazısı bulunmadığı gerekçesiyle, hizmetin geri ödemesini yapmayı reddetmekte ve bu durum adli raporların düzenlendiği sağllk kurumlarının üzerinde denetimsel ve yasal bir belirsizlik yaratabilmektedir $(4,5)$.

$\mathrm{Bu}$ çalışmada Gezi olayları çerçevesinde Mersin ilinde yapılan gösterilerde güvenlik güçlerinin müdahalelerine bağlı olarak değişik nedenlerle meydana gelen 5 yaralanma olgu serisinin adli raporlama süreçlerinde yaşanılan problemler çerçevesinde, ülkemiz açısından standart, objektif, bilimsel ilkelere dayanan ve insan hakları temelli bir yaklaşım modeli geliştirilmesi gerekliliğinin ortaya konulması amaçlanmıştır.

\section{Olgu Sunumu Olgu 1}
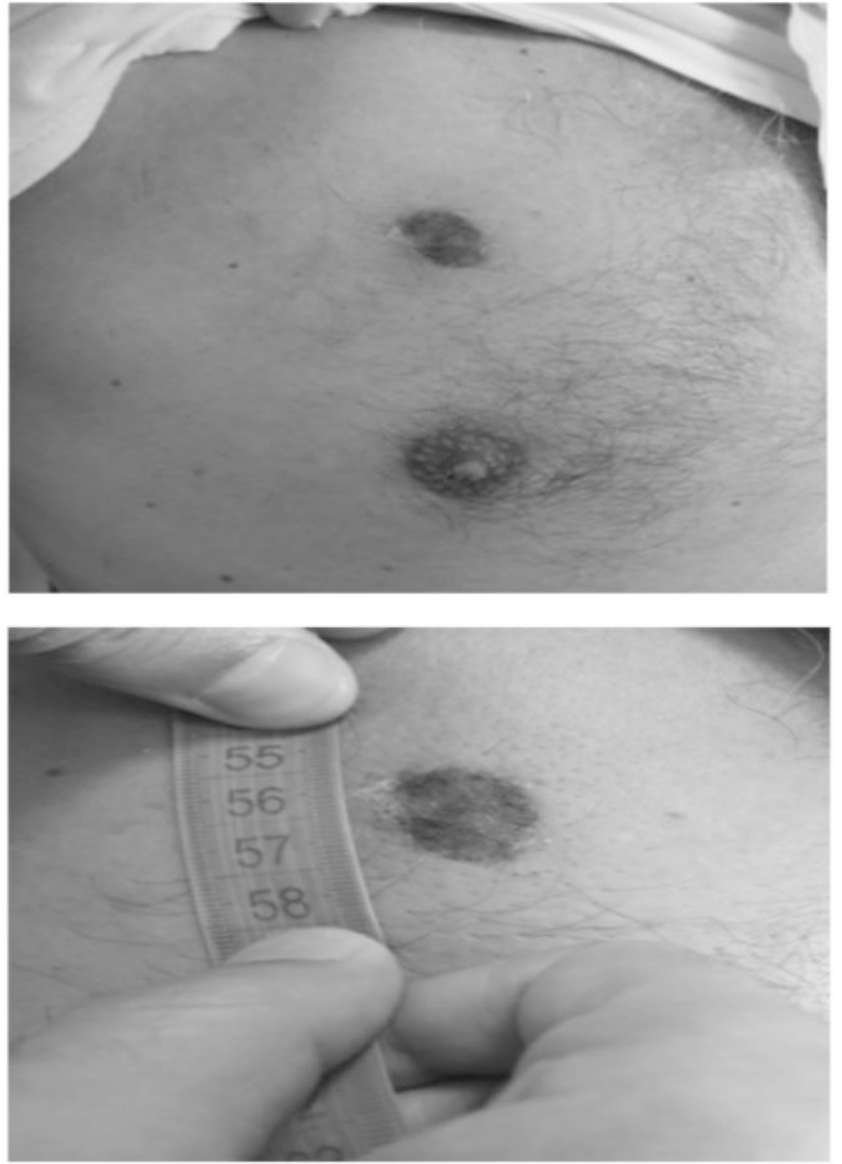

1956 doğumlu, erkek hastanın alınan öyküsünde; 20.06.2013 tarihinde (...) AVM'de gösteride iken polis tarafından plastik mermi ile yaralandığını, sağ koluna yayılan ağrı ve uyuşukluk olduğunu ifade etti. Yapılan muayenesinde; sağ göğüs bölgesinde, meme başının yaklaşı $5 \mathrm{~cm}$ üzerinde, 1,3x1,5 cm ebadında, yuvarlak-oval şekilli, zemini hemorajik, cilt altında yumuşak dokularda hematom ve ödeme bağlı şişlik palpe edilen, etrafı aksiller bölgeye doğru daha yoğun olmak üzere mor renkli yüzeyel ekimozlu, abrazyon tespit edildi. Nöroloji, Göğüs Cerrahi ve Psikiyatri Anabilim Dallarından konsültasyon istendi.

Göğüs Cerrahi Anabilim Dalı'nda 21.06.2013 tarihinde yapılan muayenesi ve hastanın yapılan SFT'de; FEV1:2.37 (\%70) , FVC 3.46 olarak ölçülmüş olup incelenen PA AC grafisinde Göğüs Cerrahisi açısından müdahale edilecek pnömotoraks / hemotoraksa rastlanmadığı belirtilmektedir.

Nöroloji Anabilim Dalı'nda 21.06.2013 tarihinde yapılan nörolojik muayenesinin normal olduğu belirtilmektedir.

Psikiyatri Anabilim Dalı'na ise kişinin başvurmadığı tespit edildi.

Kişiye ait belgelerin incelenmesi ve yapılan muayenesi sonucunda; sağ göğüs bölgesinde, meme başının yaklaşık $5 \mathrm{~cm}$ üzerinde, 1,3x1,5 cm ebadında, yuvarlak-oval şekilli, zemini hemorajik cilt altında yumuşak dokularda hematom ve ödeme bağlı şişlik palpe edilen, etrafı aksiller bölgeye doğru daha yoğun olmak üzere mor renkli yüzeyel ekimozlu, abrazyon saptanmış olup yaralanmanın lokalizasyonu, şekli ve rengi itibari ile "kişinin öyküsünde tanımladığı plastik mermi yaralanma öyküsü ile uyumlu olduğu”, tespit edilen mevcut yaralanmasının; kişinin yaşamını tehlikeye uğratmadığını, basit tıbbi müdahale ile giderilebilecek nitelikte olduğunu, kişide herhangi bir kırık tarif ve tespit edilmediğini, yüz sınırları içerisinde "Yüzde sabit iz" niteliğinde herhangi bir yaralanmasının tarif ve tespit edilmediğini, "Duyularından veya organlarından birinin işlevinin sürekli zayıflaması veya yitirilmesi" niteliğinde herhangi bir anatomik eksiklik veya fonksiyonel kısitll1ık tarif ve tespit edilmediğini, kişinin psikiyatrik muayenesi açısından tekrar değerlendirilmesinin uygun olduğu kanaatini bildirir şeklinde adli raporu düzenlendi.

1984 doğumlu, erkek hasta alınan öyküsünde; 20.06.2013 tarihinde saat 20:00'da (...) AVM'de gösterilerde polis tarafından darp edildiğini ve başından yaralandığını, daha sonra vatandașlar tarafından Özel Y. Hastanesinde ilk tedavisinin yapıldığını ifade etti. Yapılan muayenesinde; oksipital bölgede $6 \mathrm{~cm}$ uzunluğunda kenarları kısmen düzensiz, üzeri sütüre yara tespit edildi. Olay nedeni ile kişinin ruh sağlığının değerlendirilmesi açısından Psikiyatri Anabilim Dalı'ndan konsültasyon istendi. 


\section{Olgu 2}
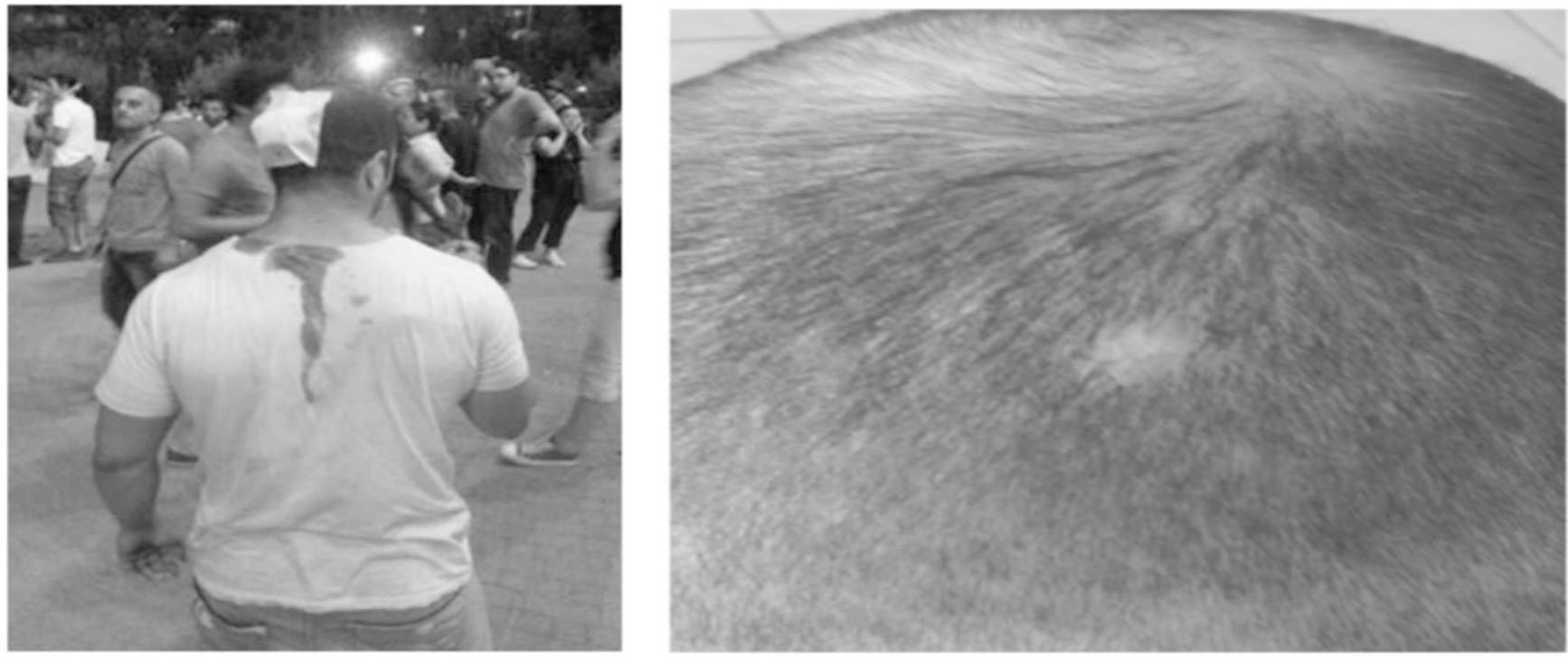

Psikiyatri Anabilim Dalında 21.06.2013 tarihinde yapılan muayenesi sonucunda; daha önce hiç psikiyatri başvurusu ve tedavi öyküsü olmadığı, önceki gün yaşadıkları sık sı gözünün önüne geldiği, olayı rüyasında görüp görmediğini hatırlamadığı, olayı yeniden yaşıyormuş gibi hissettiği, önceki gece uykuya dalma güçlügü meydana geldiği, olay aklına geldiğinde irkilme, öfkelenme olduğu, olay ile ilgili konuşmaktan rahatsız olma ve kaçınma davranışı hafif bir şekilde var olduğu, olayın bir kısmını hatırlamadığı, dikkatini yoğunlaştırma güçlüğü olduğu, sürekli tetikte olma hafif bir şekilde olduğu, hasta 10 gün sonra kontrole çağırıldığı; kontrol muayenesinde, hastanın yapılan kontrolünde keyifsizlik, her an arbede olacak gibi hissetme, güvensizlik, korku, o anı yeniden yaşama, dikkat dağınıklığı şikayetleri mevcut olduğu, hastada "Akut Stres Reaksiyonu" geliştiği tıbbi kanaatine varıldığı belirtilmektedir.

Kişiye ait belgelerin incelenmesi ve yapılan muayenesi sonucunda; oksipital bölgede kısmen düzensiz kenarlı 6 cm'lik üzeri sütüre yaralanması olduğu, olaya bağlı "Akut Stres Reaksiyonu” geliştiği, tespit edilen mevcut yaralanmasının; kişinin yaşamını tehlikeye uğratmadığını, basit tıbbi müdahale ile giderilebilecek nitelikte olduğunu, yüz sınırları içerisinde "Yüzde sabit iz" niteliğinde herhangi bir yaralanmasının tarif ve tespit edilmediğini, "Kemik kırıkları" ve "Duyularından veya organlarından birinin işlevinin sürekli zayıflaması veya yitirilmesi” niteliğinde yaralanmasının olup olmadığının belirlenebilmesi açısından kişinin muayene edilmek üzere Mersin Üniversitesi Tip Fakültesi Adli Tip Anabilim Dalı'na gönderilmesi gerektiğini, kişinin Psikiyatri Anabilim Dalı tarafından yapılan değerlendirilmesinde "Akut Stres Reaksiyonu” tanısı konulmuş olup kişin Mersin Üniversitesi Tip Fakültesi Psikiyatri Anabilim Dalı tarafindan takip ve tedavisin uygun olduğunu bildirir şeklinde raporu düzenlendi.

17.01.2014 tarihinde yapılan tekrar muayenesinde; saçlı deride oksipital bölgede $1 \times 1 \mathrm{~cm}$ ebadında nedbe tespit edildi. Psikiyatri ve Nöroloji Anabilim dallarından konsültasyonu istendi.

Nöroloji Anabilim Dalı'nda 17.01.2014 tarihinde yapılan muayenesinin normal olduğu belirtilmektedir.

Psikiyatri Anabilim Dalı'nda 17.01.2014 tarihinde yapılan muayenesi sonucunda olay sonrasında olayı yeniden yaşar gibi olma, uykuya dalma güçlügüu, ilgi azlığı, irkilme, dikkati yoğunlaştırma güçliŭgü gibi yakınmaları birkaç hafta sürüp geçtiği, olaydan bahsetmek istememe, ara ara olay aklına gelince sıkıntı hissi olduğu, şu anda keyfinin ve moralinin iyi olduğu, bilinç açık, koopere, yönelim tam, dikkat ve bellek olağan, duygulanım ötimik, çağrışımlar, düşünce içeriği, algılama ve konuşma, uyku ve iştah normal olduğu, alınan öykü ve yapilan psikiyatrik muayene neticesinde halen tan1 kriterlerini karşılayan bir ruhsal bozukluk saptanmadığ 1 belirtilmektedir.

Kişiye ait belgelerin incelenmesi ve Psikiyatri Anabilim Dalı tarafından yapılan muayenesi sonucunda oksipital bölgede $1 \times 1 \mathrm{~cm}$ nedbeye neden olan yaralanmasının; "Duyularından veya organlarından birinin işlevinin sürekli zayıflaması veya yitirilmesi” niteliğinde olmadığını bildirir şeklinde adli raporu düzenlendi. 


\section{Olgu 3}

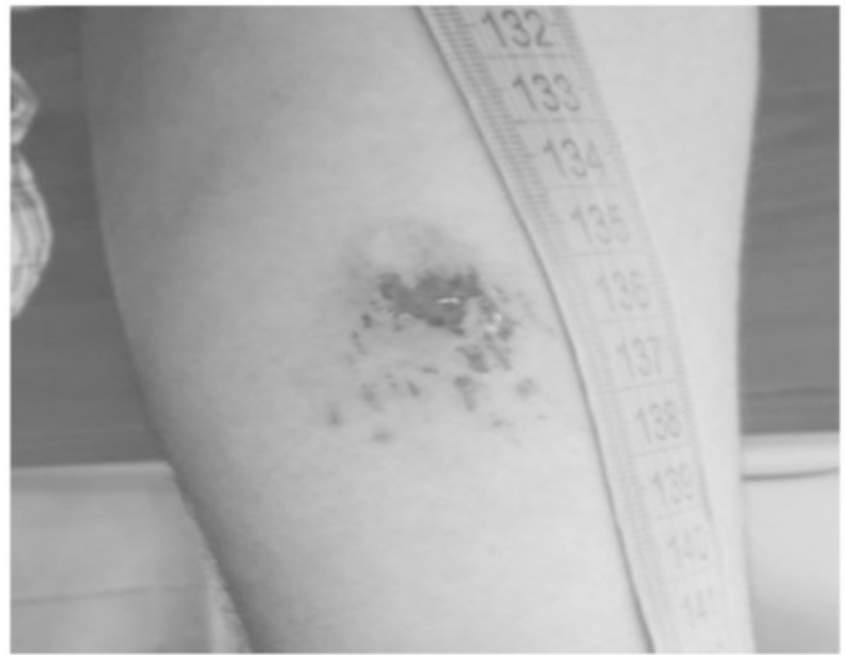

1992 doğumlu, erkek hastanın alınan öyküsünde; 20.06.2013 tarihinde, saat 20:00 civarında, (...) AVM'deki gösterilerde demokratik taleplerini dile getirirken polis tarafından plastik mermi ile yaralandığını ifade etti. Yapılan muayenesinde; sol ön kol medial yüzde 3x2 cm'lik bir alan içerisinde, düzensiz şekilli, en büyüğü $1 \times 1 \mathrm{~cm}$ olan ve çok sayıda, milimetrik ebatta, yer yer üzerleri yeni epitelize olmaya başlamış etrafları hiperemik abrazyonlar saptandı. Ölçekli fotoğrafları çekildi. Olay nedeni ile kişinin ruh sağllğgnın değerlendirilmesi açısından psikiyatri konsültasyonu istendi.

Psikiyatri Anabilim Dalı'nda 21.06.2013 tarihinde yapilan muayenesi sonucunda; önceki gün yaşadıkları sık sık gözünün önüne geldiği, olayı rüyasında gördüğü, önceki gece uykuya dalma güçlüğü, sık uyanma olmadığı, olayı yeniden yaşıyormuş gibi hissetme olmadığı, olay aklına geldiğinde irkilme, öfkelenme olduğu, travmanın hatırlamadığı bir kısmı olmadığı, olay ile ilgili konuşmaktan rahatsız olma ve kaçınma davranışı olmadığı, dikkatini yoğunlaştırma güçlüğü olmadığı, sürekli tetikte olma olmadığı, hasta bugün bir kez öfke patlaması yaşadığı, kendisini boşlukta hissetme olduğu, hastada tanı kriterlerini karşılayan psikiyatrik patoloji saptanmadığı belirtilmektedir.

K.Ç.' ye ait belgelerin incelenmesi ve yapılan muayenesi sonucunda; sol ön kol medial yüzde $3 \times 2 \mathrm{~cm}$ 'lik bir alan içerisinde, düzensiz şekilli, en büyüğü $1 \mathrm{x} 1 \mathrm{~cm}$ olan ve çok sayıda, milimetrik ebatta, yer yer üzerleri yeni epitelize olmaya başlamış etrafları hiperemik abrazyon saptanmış olup yaralanmanın lokalizasyonu, şekli ve rengi itibari ile kişinin öyküsünde tanımladığı "plastik mermi yaralanma öyküsü ile uyumlu olduğunu”, saptanan mevcut yaralanmasının; kişinin yaşamını tehlikeye uğratmadığını, basit tıbbi müdahale ile giderilebilecek nitelikte olduğunu, kişide herhangi bir kırık tarif ve tespit edilmediğini, yüz sınırları içerisinde "Yüzde sabit

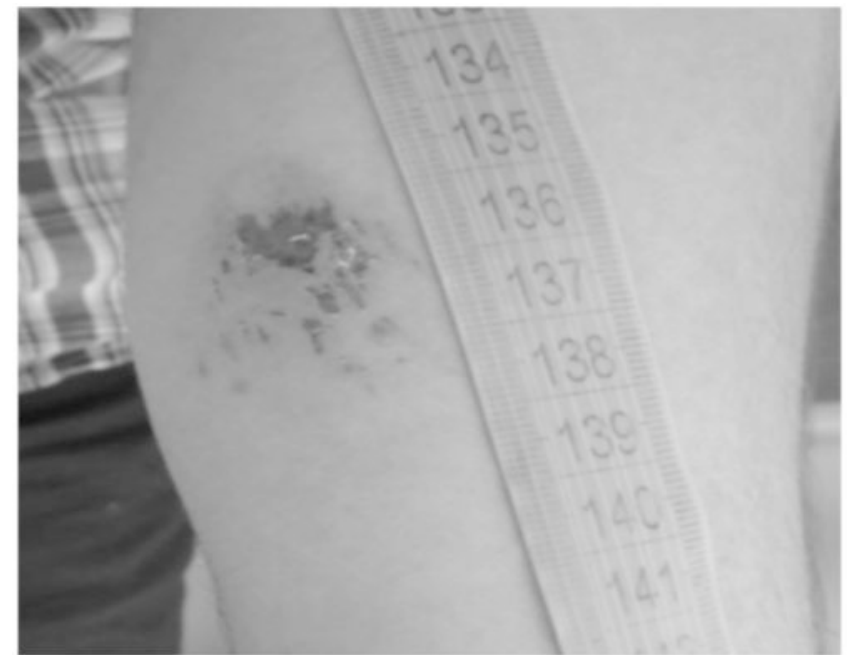

iz" niteliğinde herhangi bir yaralanmasının tarif ve tespit edilmediğini, "Duyularından veya organlarından birinin işlevinin sürekli zayıflaması veya yitirilmesi” niteliğinde herhangi bir anatomik eksiklik veya fonksiyonel kısıtlılık tarif ve tespit edilmediğini, Kişinin Psikiyatri Anabilim Dalı tarafından değerlendirilmesinde; kişide tanı kriterlerini karşılayan psikiyatrik patoloji saptanmadığı ancak travmatik olayın şiddeti, süresi, kişinin yaşı, eğitim düzeyi, kişinin mental durumu gibi etkenlerle yaşanılan travmaya bağlı psikiyatrik bulguların hayatın herhangi bir döneminde ortaya çıkabileceği kanaatini bildirir şeklinde adli raporu düzenlendi.

\section{Olgu 4}

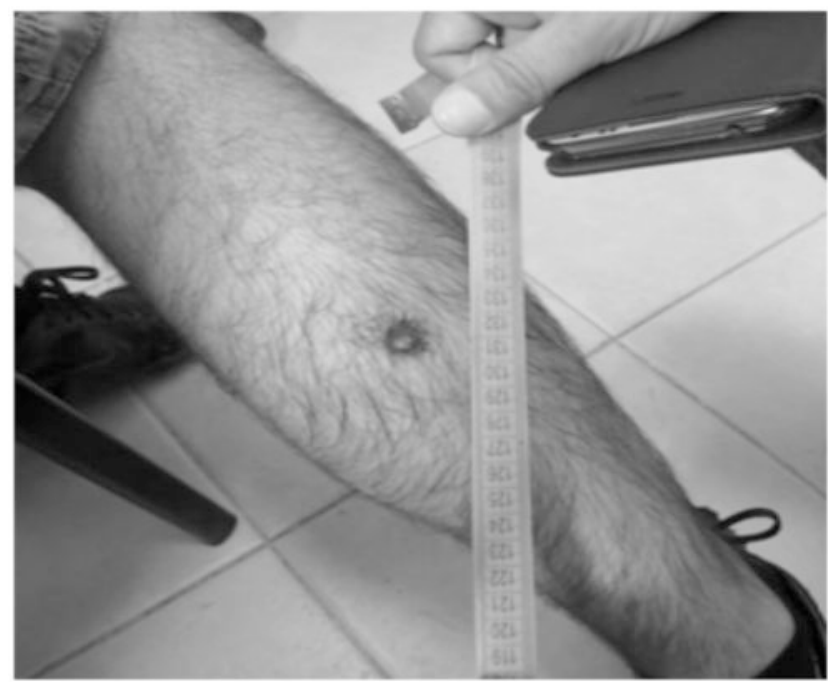

1989 doğumlu, erkek hasta alınan öyküsünde; 20.06.2013 tarihinde saat 20:00 ile 20:30 civarında (...) AVM'de gösterilerde polis tarafından plastik mermi ile yaralandığını ifade etti. Yapılan muayenesinde; sağ bacak posterior yüzde $1.5 \times 1.5 \mathrm{~cm}$ ebadında, yuvarlak şekilli, yer yer kenarları yeni epitelize olmaya ve krutlanmaya henüz başlamış, etrafı 
hiperemik halka tarzında abrazyon saptandı. Lezyonun ölçekli fotoğrafları çekildi. Olay nedeni ile kişinin psikiyatrik durumunun tespiti açısından psikiyatri konsültasyonu istendi.

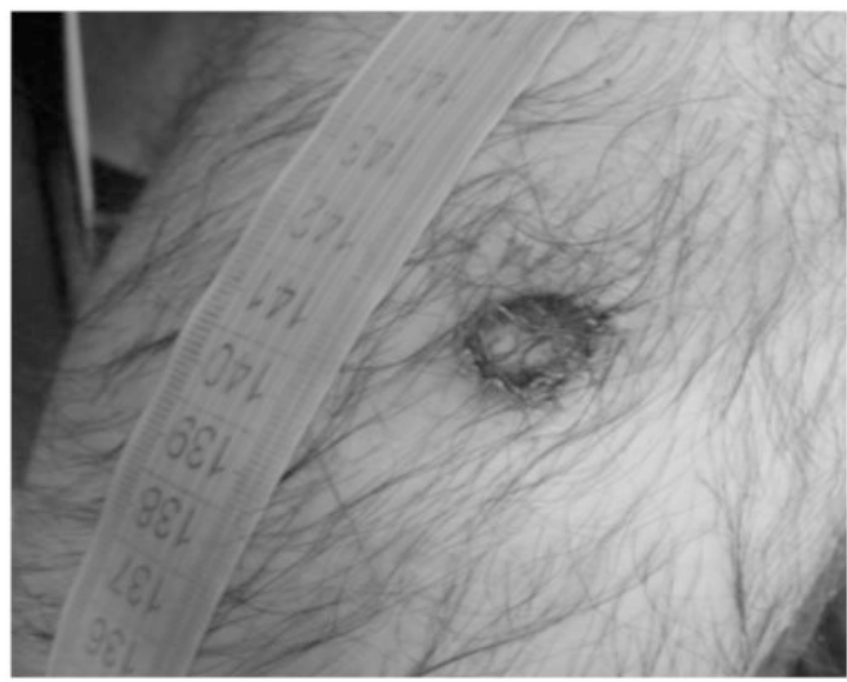

Psikiyatri Anabilim Dalı'nda 21.06.2013 tarihinde yapılan muayenesi sonucunda; daha önce hiç psikiyatri başvurusu ve tedavi öyküsü olmadığı, önceki gün yaşadıkları sık sık gözünün önüne geldiği, olayı rüyasında görüp görmediğini hatırlamadığı, bacağındaki ağrı nedeniyle gece sık sık uyanması olduğu, olay aklına geldiğinde irkilme, öfkelenme olduğu, önceki akşamdan beri hiçbir şey yemek istemediği, olayı yeniden yaşıyormuş gibi hissettiği, olay ile ilgili konuşmaktan rahatsız olma ve kaçınma davranışı olmadığı, olayın bir kısmını hatırlamadığını, dikkatini yoğunlaştırma güçlüğui olduğu, sürekli tetikte olma ve aşırı irkilme olmadığı, hastada tanı kriterlerini karşılayan psikiyatrik patoloji saptanmadığı belirtilmektedir.

H.B.'ye ait belgelerin incelenmesi ve yap1lan muayenesi sonucunda; Sağ bacak posterior yüzde $1.5 \times 1.5 \mathrm{~cm}$ ebadında, yuvarlak şekilli, yer yer kenarları yeni epitelize olmaya ve krutlanmaya henüz başlamış, etrafı hiperemik halka tarzında abrazyon saptanmış olup yaralanmanın lokalizasyonu, şekli ve rengi itibari ile kişinin öyküsünde tanımladığı "plastik mermi yaralanma öyküsü ile uyumlu olduğunu”, tespit edilen mevcut yaralanmasının; kişinin yaşamını tehlikeye uğratmadığını, basit tıbbi müdahale ile giderilebilecek nitelikte olduğunu, kişide herhangi bir kırık tarif ve tespit edilmediğini, yüz sınırları içerisinde "Yüzde sabit iz" niteliğinde herhangi bir yaralanmasının tarif ve tespit edilmediğini, "Duyularından veya organlarından birinin işlevinin sürekli zayıflaması veya yitirilmesi” niteliğinde herhangi bir anatomik eksiklik veya fonksiyonel kısıtlılık tarif ve tespit edilmediğini, kişinin Psikiyatri Anabilim Dalı tarafından değerlendirilmesinde; kişide tanı kriterlerini karşılayan psikiyatrik patoloji saptanmadığı ancak travmatik olayın şiddeti, süresi, kişinin yaşı, eğitim düzeyi, kişinin mental durumu gibi etkenlerle yaşanılan travmaya bağlı psikiyatrik bulguların hayatın herhangi bir döneminde ortaya çıkabileceği kanaatini bildirir şeklinde adli raporu düzenlendi.

Kişisel başvuru hakkı çerçevesinde, Adli Tıp Anabilim Dalımıza dilekçe ile başvuran hastaların başvuruları normal poliklinik girişi şeklinde Nucleus Medikal Bilgi Sistemine kayıtları yapılarak gerçekleştirildi. Faturalandırma işlemi ise sadece poliklinik muayenesini içerecek şekilde ücretli hasta ya da Sosyal Güvenlik Kurumuna faturalandırma şeklinde yapıldı.

Kişiler düzenlenen raporları ile Cumhuriyet Savcılıklarına suç duyurusunda bulundular. Cumhuriyet Savcılıklarınca bazı olgular için üst yazı yazılarak gerek Anabilim Dalımızdan, gerekse Adli Tıp Şube Müdürlüğü'nden tekrar adli rapor düzenlenmesi istenildi.

\section{Tartışma}

Travmaya uğramış her bireyin, travmanın öyküsünden ve oluş şeklinden bağımsız olarak, kendi sağlık durumunun tespiti, kayıt altına alınması ve belgelenmesi ile yaralanmalarının tedavisi hususlarında sağlık kuruluşlarına başvuru hakkı bulunmaktadır. Bu hak (sağlık hakkı) hem T.C. Anayasası hem de Uluslar arası antlaşmalar ve bildirgeler tarafından güvence altına alınmış temel bir insan hakkıdır. Ayrıca Dünya Tabipler Birliği'nin Uluslararası Hekimlik Etiği (Ekim 1949), Mesleki Bağlılık Yemini Cenevre Bildirgesi (Eylül 1948), Hasta Hakları Lizbon Bildirgesi (Eylül-Ekim 1981), İnsan Hakları Bildirgesi (Ekim 1990), Şiddet ve Sağlık İlişkisine İlişkin Bildirgesi (Mayıs 2003) ve İşkence ya da Zalimce/İnsanlık Dışı/Onur Kırıcı Muamelelerin Belgelendirilmesi ve İhbar Edilmesinde Hekimlerin Sorumluluğuna İlişkin Kararı (Eylül 2012) ve Biyoloji ve Tıbbın Uygulanması Bakımından İnsan Hakları ve İnsan Haysiyetinin Korunması Sözleşmesi Tasarısı: İnsan Hakları ve Biyotıp Sözleşmesi gibi birçok uluslararası antlaşmalar ve bildirgeler de "sağlık hakkını" temel insan hakkı olarak görmekte ve bu hususta hekimlerin tavrının ve rolünün ne olması gerektiğini açıkça ortaya koymaktadır $(6,7)$. Toplumsal olaylarda güvenlik güçlerinin müdahalelerine bağlı yaralananlar da birer travma hastasıdır ve tüm diğer travma hastaları gibi istediği sağlık kuruluşuna başvurarak kendi sağlık durumunun tespiti, tedavisi, kayıt altına alınması ve belgelenmesini talep etme hakkına sahiptir. Sağlık kuruluşlarının diğer travma olgularından farklı olarak bu olgular için ilk başvuru aşamasında resmi yazı talep etmesi uygun bir yaklaşım değildir. Olguları diğer tüm travma olguları gibi kabul ederek, öykülerini alıp gerekli fizik muayene, laboratuar ve görüntüle yöntemleri ile tanılarını sonucu tedavileri yapıldıktan sonra adli bildirimleri gerçekleştirilmeli ve adli olgu olarak 
tanımlanmalıdır. Her sağlık mesleği mensubu Türk Ceza Kanunu'nun 280. Maddesine göre; görevini yaptığı sırada bir suçun işlendiği yönünde bir belirti ile karşılaştığında durumu yetkili makamlara bildirmek zorundadır. Ceza Muhakemesi Kanunu'nun 158. Maddesine göre adli bildirim; Cumhuriyet Başsavcılığına veya kolluk makamlarına yapılabilmektedir (811). Bu olguların başvurularını kabul etmeyen, gerekli ve yeterli sağlık hizmetini vermeyen, lezyonların tespitini ve dokümantasyonunu yapmayan ve adli olgu bildiriminde bulunmayan hekimlerin bu davranışları nedeniyle "insan hakları ihlallerine katılımı" söz konusu olabilmektedir. İnsan hakları ihlalleri nedeniyle ülkemizin uğradığı zararların, sorumlularına rücu ettirileceği yönünde kanuni düzenlemeler mevcuttur. Bu konuda, yapandan ziyade; yapilma emri veren, göz yuman, denetlemeyen ve rapor etmeyenlerin sorumlu olduğu kabul edilmektedir. Hekimler kendilerine başvuran toplumsal olaylarda güvenlik güçlerinin müdahalelerine bağlı yaralanma olgularının tanısı, tedavisi, lezyonların tespiti, dokümantasyonu ve adli olgu bildirimi ile mükelleftirler. Ancak adli olgu bildirimi yapılırken başvuranın iyilik hali ve yüksek yararı da gözetilerek, gerektiği durumlarda ruhsal destek sonrası ve başvuranın da belirleyeceği bir zaman dilimi içerisinde tekrar değerlendirilmeli ve adli bildirim buna göre yapilmalidir.

Sonuç olarak; toplumsal olaylarda güvenlik güçlerinin müdahalelerine bağlı yaralanmaların tespit, tedavi, adli raporlama ve hukuksal süreçleri açısından; sağlık kurumlarında gerekli birimlerin kurulması gerektiğini ve bu tür başvuruların da öncelikli hasta olarak değerlendirilmesi gerektiğini düşünmekteyiz. Bu kişilerin tüm hastanelere bireysel başvuru hakkı olması gerektiğini ve bu başvurularının sosyal devlet olma ilkesinin bir gereği olarak sosyal güvenlik kurumunca karşılanması uygun olacaktır. Bireysel başvuruların, adli raporlama süreçlerinin ve hukuksal hakların garanti altına alınması için her ilin Barosunda güncel ve süreklilik arz eden birimlerin bulunması gerektiği ve bunların iletişim bilgilerinin ve adreslerinin basın, yayın ve internet yoluyla duyurulması yerinde olacaktır. Bireysel başvuru hakkı çerçevesinde düzenlenen adli raporların olay tarihine en yakın ve güncel, objektif ve bağımsız raporlar olduğu dikkate alındığında; Cumhuriyet Savcılıklarınca olay üzerinden süre geçtikten sonra tekrar rapor aldırılmasını engellemek ve başvuru hakkı çerçevesinde düzenlenen adli raporların üst düzeyde geçerliliğini sağlamak amacıyla gerekli yasal düzenlemelerin yapılması gerektiği ortaya çıkmaktadır.

\section{Kaynaklar}

1. Adli Tip Kurumu Kanunu. Kanun Numarası: 2659 Kabul Tarihi: 14/04/1982 Resmi Gazete Tarihi: 20/04/1982 Resmi Gazete Sayıs1: 17670 www.atk.gov.tr/AdlitipKurumu Kanunu.html (Erişim tarihi: 11.09.2014)

2. Ateş S, Turgut K. "Toplumsal Olaylarda Aşırı Güç Kullanımının Sebepleri” İnceleme Araştırma Raporu. T.C. İçişleri Bakanlığı Mülkiye Müfettişliği. Sayı: S.A. 152/13 K.T.19/13.

3. T.C. Sağlık Bakanlığı Temel Sağlık Hizmetleri Genel Müdürlüğü B.10.0.TSH.013.003- 13292 22.09.2005 sayılı Adli Tabiplik Hizmetlerinin Yürütülmesinde Uyulacak Esaslar, Genelge 2005/143 http://www.ttb.org.tr/mevzuat/index.php?option= com_content\&view=article \&id=95:adltabl-hmetler-ymesdeuyulacak-esaslar\&catid=3:tebligenelge \&Itemid=35 (Erişim tarihi: 11.09.2014)

4. T. C. Sağlık Bakanlığı Sağlık Hizmetleri Genel Müdürlüğü 64047795/23642684/010-06/165 sayılı Adli Olaylara Taraf Kişiler Hakkında Tedavi ve Denetimli Serbestlik Tedbirine Hükmedilenler ile Tutuklu ve Hükümlü Tedavi Giderleri Hakkında Genelge http://www.saglik.gov.tr/HM /dosya/178875/h/tutuklu-genelge-2013-2.pdf (Erişim tarihi: 11.09.2014)

5. T.C. Sağlık Bakanlığı Sağlık Hizmetleri Genel Müdürlüğü Sosyal Güvenlik Uygulamaları Daire Başkanlı̆̆ 1 B.10.0.SHG.0.20. 00.00/010.06/7007 sayıll, 16/05/2012 tarihli, Adli Vakalara Ait Fiyat Tarifesi Genelge 2012/22 www.saglik.gov.tr/TR/dosya/175854/h/genelge-2012-22.doc (Erişim tarihi: 11.09.2014)

6. Türkiye Cumhuriyeti Anayasası. Kanun No.: 2709 Kabul Tarihi: 7.11.1982 http://www.tbmm.gov.tr/anayasa/ anayasa_2011.pdf (Erişim tarihi: 11.09.2014)

7. Sayek F. Sağlıkla İlgili Uluslararası Belgeler: Dünya Tabipler Birliği, Avrupa Konseyi, Birleşmiș Milletler, Unesco, Avrupa Tabip Birlikleri Forumu Füsun Sayek TTB Raporları/ Kitapları -2009. Türk Tabipleri Birliği Yayınları. İkinci Baskı, Ekim 2009, Ankara.

8. Türk Ceza Kanunu. Kanun Numarası: 5237 Kabul Tarihi: 26/09/2004 http://www.ceza-bb.adalet.gov.tr/mevzuat/ 5237.htm (Erişim tarihi: 11.09.2014)

9. Tümer AR, Keten A, Karacaoğlu E. Adli olgu bildirimi ve adli raporlar. Hacettepe Tip Dergisi 2010; 41:128-134.

10. Çekin N, Gülmen MK, Hilal A, Salaçin S. Türkiye'de hekimlerin ihbar yükümlülüğü ile ilgili etik sorunlar. Adli Tıp Bülteni 1999; 4(1):11-5.

11. Ceza Muhakemesi Kanunu. Kanun Numarası: 5271 Kabul Tarihi: 04/12/2004 http://www.ceza-bb.adalet.gov.tr/ mevzuat/ 5271.htm (Erişim tarihi: 11.09.2014) 